\title{
The effects of physical activity during childhood, adolescence, and adulthood on cardiovascular risk factors among adults
}

\author{
(iD)André O. Werneck ${ }^{1}$ \\ (iD) Ricardo R. Agostinete ${ }^{1}$ \\ (iD) Manoel Carlos S. de Lima' \\ (iD)Bruna C. Turi-Lynch² \\ (iD) Romulo A. Fernandes ${ }^{1}$
}

1. Laboratório de Investigação em Exercício (LIVE), Departamento de Educação Física, Universidade Estadual Paulista (UNESP), Presidente Prudente, SP, Brasil. 2. Assistant Professor. Department of Physical Education and Exercise Science. Lander University. 320 Stanley Ave, Greenwood, SC, USA.

\section{SUMMARY}

OBJECTIVES: To analyze the association between physical activity during life and cardiovascular risk factors among adults.

DESIGN: The sample was composed of 101 adults (59 men) between 30 and 50 years old, who were recruited from different gyms and from a University in Brasil. Participants were divided according to their engagement in sports in early life (self-reported) and current physical activity (pedometer) (sports participation during childhood/adolescence and currently active [ $n=26]$, sports participation during childhood/ adolescence and currently inactive [n=26], and control [n=49]). Cardiovascular risk factors were measured, such as body fat (through DXA), HDL-C, triglycerides, HOMA index, systolic blood pressure, diastolic blood pressure, and C-reactive protein. We adopted the covariates of chronological age, sex, alcohol consumption, tobacco, and body mass index. General estimating equations were used, with $p<0.05$. Results: After the adjustments of the final model, individuals engaged in sports during childhood and adolescence and inactive during adulthood presented lower body fat, when compared to participants persistently inactive $(p<0.001)$. Participants persistently active presented lower body fat $(p<0.001)$ and lower c-reactive protein $(p=0.010)$ when compared to the control group.

CONCLUSION: Early sports participation was associated with reduced body fat, and being physically active throughout life was associated with reduced body fat and C-reactive protein.

KEYWORDS: Motor activity. Sports. Chronic disease. Exercise.

\section{INTRODUCTION}

Physical activity is recognized as a protective factor for several diseases during adulthood ${ }^{1-3}$. Physical activity during childhood and adolescence can also affect cardiovascular diseases, through indirect pathways, as the maintenance of physical activity practice, or protecting against morbidities developed during childhood and adolescence, and prolonged to adulthood ${ }^{4-5}$. However, recent evidence

DATE OF SUBMISSION: 18-Mar-2019

DATE OF ACCEPTANCE: 31-Mar-2019

CORRESPONDING AUTHOR: André O. Werneck

Departamento de Educação Física, Universidade Estadual Paulista (UNESP)

Rua Roberto Símonsen, 305 - Presidente Prudente, São Paulo, Brasil - Zipcode: 19060-900

Tel: +55 (18) 3229-5388

E-mail: andreowerneck@gmail.com 
highlights a possible direct association between physical activity during early ages and cardiovascular diseases during adulthood, particularly through epigenetics ${ }^{5-6}$.

Similarly, in addition to the association between early physical activity and prospective cardiovascular outcomes through direct pathways ${ }^{2,7}$, the literature has shown that the benefits can be greater among individuals who remain active throughout life ${ }^{8}$. However, this issue is not clear among adults.

In this sense, our aim was to analyze the association between physical activity during childhood, adolescence, and adulthood, and cardiovascular risk factors among adults.

\section{METHODS}

\section{Sample}

The present study has been carried out in Presidente Prudente, a middle-sized city located in the western region of Sao Paulo State, Brasil. The sample comprised 122 adults (69 men and 53 women), aged between 30 and 50 years old who were recruited in fitness clubs (spread out in different regions of the city) and in the campus of the Sao Paulo State University (fitness clubs, $n=100$; university staff, $n=22$ ). The sample size calculation was based on an equation for correlation, which indicated the need to evaluate at least 114 subjects to detect correlation coefficients of $r=0.26$, with a power of $80 \%$ and a statistical significance of $5 \%$.

To participate in the study, the individuals fulfilled all inclusion criteria previously established: (i) Sports participation in early life (both childhood and adolescence) or absence of sports participation in early life (control group); (ii) aged between 30 and 50 years old; (iii) no previous history of stroke or infarction; (iv) no amputation or visual impairment due to diabetes mellitus. Due to missing data, 15 (five men) individuals were excluded from the sample; moreover, six individuals were excluded because they did not practice physical activity during childhood and adolescence and became physically active during adulthood. All participants agreed to participate and signed a consent form. The study protocol was previously approved by the Research Ethics Committee of the University. More detailed procedures were previously published ${ }^{9}$. Thus, the final sample included 101 subjects (59 men and 42 women).

\section{Early sports participation and current physical} activity

Early sports participation, which comprised the period of childhood and adolescence, was assessed by two questions: 1) "Outside of school, did you engage in any organized/supervised sports for at least one year between agews seven and ten?"; 2) “Outside of school, did you engage in any organized/supervised sports for at least one year between the ages of 11 and 17?". Early sports participation was adopted as one of the inclusion criteria of the study; therefore, only participants who responded "yes" or "no" to both questions were included in the study.

Current physical activity (Current-PA) was monitored using a pedometer (Digi- Walker Yamax, SW200) for seven consecutive days. At the end of each day, the participant recorded the number of steps accumulated, and, in the following morning, the device was reset to start a new count. The mean number of steps of the week was used in the analyses.

\section{Body fat}

Body fat was estimated through the use of a Dual Energy X-ray Absorptiometry device (DXA) (Lunar Model - DPX-NT General Electric [GE] $\left.{ }^{\circledR}\right)$. Body fat was expressed in percentage (\%BF) using a GE Medical Systems Lunar software, version 4.7.

\section{Cardiovascular risk factors}

The measurement of systolic (SBP) and diastolic blood pressure (DBP) were performed according to the Brazilian guidelines of hypertension ${ }^{10}$. The participants were evaluated three times with an interval of one minute between each measurement. The final value of blood pressure was the average of the last two measurements.

To measurement of metabolic variables and inflammatory marker (high sensitive C-reactive protein [hsCRP]), collection of blood samples and biochemical analyses were performed in a private laboratory that met the criteria of standardization and quality control adopted by the Brazilian Health Ministry. Blood samples were collected after a fasting period of 12 hours. To calculate the HOMA-IR (Homeostatic Model Assessment-Insulin resistance), we used the dosage of fasting blood glucose $(\mathrm{mmol} / \mathrm{L})$ and insulin $(\mathrm{IU} / \mathrm{mL})$ applying the formula: HOMA-IR $=\left(\right.$ Fasting glucose ${ }^{*}$ insulin $) \div$ $22.5^{11}$. To measure the fasting glucose, total cholesterol (TC), triglycerides (TG), and high-density 
lipoprotein cholesterol (HDL-C), an enzymatic colorimetric kit processed in an Autohumalyzer A5 unit was used.

\section{Covariates}

Current smoking (yes or no) and alcohol consumption (weekly consumption) were accessed through a face-to-face interview. To estimate body mass index, we measured height using a stadiometer (Standard, Sanny ${ }^{\circledR}$, Brasil), with a precision of $0.1 \mathrm{~cm}$ and body mass was measured using a digital scale (PL 200, Filizola, Brasil), with a precision of $0.1 \mathrm{~kg}$.

\section{Statistical analyses}

Descriptive statistics was composed of mean and standard deviation. The Mann-Whitney test was used to compare groups, while general estimating equations (GEE) were used to compare individuals with early sports participation and physically active, early sports participation and physically inactive, and no sports participation and physically inactive, adjusted by covariates. Statistical significance (p-value) was set at 0.05, and the statistical software STATA (version 15.1) was used in all analyses.

\section{RESULTS}

The final sample included 101 adults (59 men) between 30 and 50 years old; the characteristics of the sample are presented in Table 1. In general, men presented higher systolic blood pressure $(\mathrm{p}<0.001)$, diastolic blood pressure $(\mathrm{p}<0.001)$, and triglycerides $(\mathrm{p}=0.001)$, and lower HDL-C $(\mathrm{p}<0.05)$. On the other hand, women presented more body fat $(p<0.001)$.

General estimating equation models of the association between cardiovascular risk variables and physical activity maintenance patterns are presented in Table 2 . Model 1 is adjusted by chronological age and sex. Both the group of physical activity only during childhood and adolescence and the group of physical activity during childhood/adolescence and adulthood presented lower body fat (\%), Triglycerides, HOMA, and C-reactive protein as well as greater HDL-C $(p<0.001)$ compared to the control group.

After the first set of analyses, models were also adjusted by other covariates (tobacco smoking, alcohol consumption, and BMI) (model 2). The variables that remained significant were body fat, triglycerides, and HOMA. The C-reactive protein was significantly lower only for the group of individuals physically active during childhood, adolescence, and adulthood. After this, significant values from model 2 were included as covariates in model 3 (body fat, triglycerides, HOMA, and C-reactive protein) in addition to the other covariates. The group of physical activity during childhood and adolescence but not during adulthood, and the group of physical activity during childhood, adolescence, and adulthood presented lower body fat (Wald $=54.91$; $\mathrm{p}<0.001)$. On the other hand, only the group of physical activity during childhood, adolescence, and adulthood remained with lower C-reactive protein (Wald=9.16; $p=0.010$ ).

\section{DISCUSSION}

Our main findings were that after the adjustment for all covariates, individuals who were physically active during childhood and adolescence, but were not physically active during adulthood, presented lower body fat when compared to the control group, while the group engaged in sports during childhood and adolescence, and still physically active during adulthood, presented lower body fat and C-reactive protein when compared to the control group.

This finding is consistent with the classic hypothesis that physical activity during childhood and adolescence can affect later body composition through modifications in body fat induced during the early ages and prolonged to adulthood ${ }^{4,5,12}$. Also, concerning the direct association of early sports participation with reduced body fat, physical exercise can promote DNA methylation in some genes associated with body adiposity ${ }^{13}$, having a direct association in this path.

On the other hand, only the group with physical activity during childhood, adolescence, and adulthood presented lower C-reactive protein. This finding can be explained because C-reactive protein is more dependent on the current levels of physical activity ${ }^{14}$, especially because C-reactive protein is an indicator of the actual inflammation process. In this sense, the role of previous physical activity should pass through the maintenance of physical activity from childhood to adulthood ${ }^{2}$. Another potential mechanism of this association should be body-fat maintenance throughout life, which is an important factor related to C-reactive $\operatorname{protein}^{15}$, and, in our study, presented association 
TABLE 1. CHARACTERISTICS OF THE SAMPLE ( $\mathrm{N=101)}$

\begin{tabular}{|c|c|c|c|}
\hline Variables & $\begin{array}{l}\text { Men } \\
(n=59)\end{array}$ & $\begin{array}{l}\text { Women } \\
(n=42)\end{array}$ & $\mathrm{p}$ \\
\hline Chronological age (years) & $39.3 \pm 5.8$ & $40.2 \pm 6.8$ & 0.513 \\
\hline BMI $\left(\mathrm{kg} / \mathrm{m}^{2}\right)$ & $27.2 \pm 3.8$ & $25.3 \pm 5.0$ & 0.004 \\
\hline Body fat (\%) & $27.3 \pm 8.2$ & $37.3 \pm 10.9$ & $<0.001$ \\
\hline Systolic blood pressure (mmHg) & $117.3 \pm 9.8$ & $104.5 \pm 11.9$ & $<0.001$ \\
\hline Diastolic blood pressure $(\mathrm{mmHg})$ & $81.4 \pm 5.5$ & $74.8 \pm 7.6$ & $<0.001$ \\
\hline HOMA (score) & $1.63 \pm 1.36$ & $1.27 \pm 0.91$ & 0.148 \\
\hline $\mathrm{HDL}-\mathrm{C}(\mathrm{mg} / \mathrm{dL})$ & $47.1 \pm 9.9$ & $58.9 \pm 12.1$ & $<0.001$ \\
\hline Tryglicerids (mg/dL) & $142.0 \pm 100.0$ & $87.7 \pm 43.7$ & 0.001 \\
\hline C-reactive protein $(\mathrm{mg} / \mathrm{dL})$ & $2.90 \pm 3.40$ & $3.69 \pm 4.55$ & 0.959 \\
\hline Mean number of steps (n) & $8,314 \pm 3,494$ & $8,324 \pm 3,399$ & 0.995 \\
\hline Current physically active (\%) & $25.4 \%$ & $27.9 \%$ & 0.931 \\
\hline Early sports practice (\%) & $54.2 \%$ & $46.5 \%$ & 0.512 \\
\hline Tobacco smoking (\%) & $6.8 \%$ & $0 \%$ & 0.085 \\
\hline Alcohol drinking ( $\geq 2 \times$ week) $(\%)$ & $20.3 \%$ & $11.9 \%$ & 0.264 \\
\hline
\end{tabular}

Values are presented in means and standard deviations BMI, body mass index.

TABLE 2. GENERAL ESTIMATING EQUATIONS OF THE ASSOCIATION BETWEEN PHYSICAL ACTIVITY PATTERNS AND CARDIOVASCULAR RISK FACTORS ( $\mathrm{N}=101)$.

\begin{tabular}{|c|c|c|c|c|c|}
\hline \multicolumn{6}{|c|}{ Physical activity patterns } \\
\hline & $\begin{array}{l}\text { Control } \\
(n=49)\end{array}$ & $\begin{array}{l}\text { Early practice / inactive } \\
(n=26)\end{array}$ & $\begin{array}{l}\text { Early practice / active } \\
(n=26)\end{array}$ & & \\
\hline & Mean $(95 \% \mathrm{Cl})$ & Mean $(95 \% \mathrm{Cl})$ & Mean $(95 \% \mathrm{Cl})$ & Wald & $p$ \\
\hline \multicolumn{6}{|l|}{ Model 1} \\
\hline Body fat (\%) & $37.8(36.3$ to 39.5$)$ & $26.0(23.5 \text { to } 28.7)^{a}$ & $23.6(21.0 \text { to } 26.6)^{a}$ & 90.21 & $<0.001$ \\
\hline $\mathrm{HDL}-\mathrm{C}(\mathrm{mg} / \mathrm{dL})$ & 47.6 (45.3 to 50.1$)$ & $55.3(51.1 \text { to } 59.8)^{\mathrm{a}}$ & $55.7(51.8 \text { to } 60.0)^{\mathrm{a}}$ & 16.77 & $<0.001$ \\
\hline Triglycerides (mg/dL) & 144.3 (125.3 to 166.3$)$ & $84.0(71.8 \text { to } 98.3)^{a}$ & $90.9(70.1 \text { to } 117.8)^{a}$ & 27.76 & $<0.001$ \\
\hline HOMA (score) & 2.06 (1.71 to 2.47 ) & $0.95(0.78 \text { to } 1.15)^{a}$ & $0.87(0.74 \text { to } 1.02)^{a}$ & 54.01 & $<0.001$ \\
\hline Systolic blood pressure $(\mathrm{mmHg})$ & 113.8 (110.8 to 116.9) & 110.3 (106.5 to 114.2$)$ & 109.5 (106.0 to 113.0) & 4.09 & 0.130 \\
\hline Diastolic blood pressure $(\mathrm{mmHg})$ & $79.8(77.8$ to 81.8$)$ & 78.1 (76.3 to 79.9$)$ & 76.7 (74.4 to 79.1$)$ & 4.10 & 0.129 \\
\hline C-reactive protein (mg/dL) & 4.76 (3.69 to 6.13$)$ & $2.20(1.22 \text { to } 3.98)^{a}$ & $1.30(0.85 \text { to } 1.98)^{\mathrm{a}}$ & 29.11 & $<0.001$ \\
\hline \multicolumn{6}{|l|}{ Model 2} \\
\hline Body fat (\%) & 35.0 (33.7 to 36.4$)$ & $27.48(25.5 \text { to } 29.7)^{\mathrm{a}}$ & $24.72(22.7 \text { to } 26.9)^{\mathrm{a}}$ & 66.65 & $<0.001$ \\
\hline $\mathrm{HDL}-\mathrm{C}(\mathrm{mg} / \mathrm{dL})$ & 49.1 (46.6 to 51.8$)$ & 53.5 (49.6 to 57.8$)$ & 53.8 (50.3 to 57.7$)$ & 4.89 & 0.087 \\
\hline Triglycerides (mg/dL) & 132.3 (118.4 to 147.8) & $89.63(75.8 \text { to } 105.9)^{a}$ & $96.03(73.7 \text { to } 125.1)^{\mathrm{a}}$ & 15.64 & $<0.001$ \\
\hline HOMA (score) & 1.67 (1.44 to 1.93$)$ & $1.07(0.90 \text { to } 1.27)^{a}$ & $1.01(0.85 \text { to } 1.21)^{\mathrm{a}}$ & 17.66 & $<0.001$ \\
\hline Systolic blood pressure $(\mathrm{mmHg})$ & 110.7 (108.1 to 113.3) & 113.0 (108.8 to 117.3$)$ & 112.14 (109.1 to 115.3) & 0.85 & 0.654 \\
\hline Diastolic blood pressure $(\mathrm{mmHg})$ & 78.8 (76.9 to 81.1) & 78.98 (76.9 to 81.1) & 77.48 (75.3 to 79.8$)$ & 1.16 & 0.560 \\
\hline C-reactive protein (mg/dL) & 4.08 (3.18 to 5.22) & 2.41 (1.35 to 4.31$)$ & $1.44(0.95 \text { to } 2.18)^{a}$ & 17.51 & $<0.001$ \\
\hline \multicolumn{6}{|l|}{ Model 3} \\
\hline Body fat (\%) & 34.8 (33.3 to 36.3$)$ & $27.5(25.6 \text { to } 29.5)^{\mathrm{a}}$ & $24.9(22.9 \text { to } 27.1)^{\mathrm{a}}$ & 54.91 & $<0.001$ \\
\hline $\mathrm{HDL}-\mathrm{C}(\mathrm{mg} / \mathrm{dL})$ & - & - & - & - & - \\
\hline Triglycerides (mg/dL) & 126.7 (107.7 to 149.1) & 92.1 (77.6 to 109.3) & 98.4 (72.5 to 133.5$)$ & 5.47 & 0.065 \\
\hline HOMA (score) & $1.43(1.24$ to 1.66$)$ & $1.18(1.02$ to 1.37$)$ & $1.14(0.97$ to 1.34$)$ & 4.11 & 0.128 \\
\hline Systolic blood pressure $(\mathrm{mmHg})$ & - & - & - & - & - \\
\hline Diastolic blood pressure $(\mathrm{mmHg})$ & - & - & - & - & - \\
\hline C-reactive protein (mg/dL) & $4.12(2.83$ to 5.99$)$ & 2.13 (1.47 to 3.09$)$ & $1.33(0.77 \text { to } 2.29)^{\mathrm{a}}$ & 9.16 & 0.010 \\
\hline
\end{tabular}

Notes. Model 1: Adjusted for sex and chronological age. Model 2: Model 1 + tobacco smoking, alcohol consumption, and body mass index. Model 3: Model 2 + Body fat, triglycerides, $\mathrm{HOMA}$, and C-reactive protein. $\mathrm{a}=\mathrm{p}<0.05 \mathrm{vs}$. control. $\mathrm{Cl}=$ confidence interval. Significant differences in bold 
with both groups (physical activity in early life but not currently, and physical activity throughout life).

Regarding the strength of our study, the adjustment of the analysis by several potential confounders, as well as the approach of adopting physical activity maintenance patterns, are the most important factors. On the other hand, our findings should be inferred with caution due to some limitations, such as reduced sample size, which did not allow us to stratify the results by sex, retrospective design, which can reduce causal inference due to super estimation of previous sports engagement, as well as the lack of socioeconomic indicator. It was not possible to include a fourth group (physical activity during adulthood, but no sports participation in childhood and adolescence) because of the low prevalence in our sample (5.6\%). Moreover, we did not present an indicator of physical fitness, which could be a potential mediator. On the other hand, we presented good measures of body fat ${ }^{16}$, direct physical activity through pedometer, and metabolic variables.

\section{CONCLUSION}

Thus, early engagement in sports (during childhood and/or adolescence, but not adulthood) was associated with reduced body fat, and physical activity during childhood, adolescence, and adulthood were associated with lower body fat and C-reactive protein, independent of potential confounders. Therefore, intervention strategies aiming to promote physical activity should be conducted even among children, aiming to impact cardiovascular health in adulthood.

\section{Funding}

This study was supported by Sao Paulo Research Foundation-FAPESP (Process: 2012/18001- 0) and Brazilian Ministry of Science and Technology-CNPq (Process: 474484/2012-2). AOW received a grant from FAPESP (Process: 2017/27234-2) and RRA received a grant from FAPESP (Process: 2017/09182-5). This study was also financed in part by the Coordenação de Aperfeiçoamento de Pessoal de Nível Superior - Brasil (CAPES) - Finance Code 001

\section{Conflict of interest}

The authors report no conflicts of interest

\section{Funding}

Sao Paulo Research Foundation (FAPESP [Process: 2012/18001- 0]) and the Brazilian Ministry of Science and Technology (CNPq [Process: 474484/2012-2]).

\section{RESUMO}

OBJETIVO: Analisar a associação entre atividade física durante a vida e fatores de risco cardiovasculares entre adultos.

DESIGN: A amostra foi composta por 101 adultos (59 homens) entre 30 e 50 anos, os quais foram recrutados em diferentes academias de ginástica e uma universidade brasileira. Os participantes foram divididos de acordo com o engajamento prévio (autorrelatado) e atual de atividade física (mensurada por pedômetro) (participação esportiva durante a infância/adolescência e prática atual [n=26], participação esportiva durante a infância/adolescência e ausência de prática atual [n=26] e controle [n=49]). Como fatores de risco cardiovasculares foram mensurados gordura corporal (por meio de DXA), HDL, triglicérides, índice Homa, pressão arterial sistólica e diastólica, além da proteína c-reativa. Foram adotadas como covariáveis: idade cronológica, sexo, consumo de álcool e índice de massa corporal. Equações gerais de estimativa foram utilizadas adotando $p<0,05$.

RESULTADOS: Após os ajustes no modelo final, indivíduos engajados em esporte durante a infância e adolescência e inativos durante a idade adulta apresentaram menor gordura corporal quando comparados com participantes persistentemente inativos ( $p<0,001)$. Participantes persistentemente ativos apresentaram menor gordura corporal $(p<0,001)$ e proteína c-reativa $(p=0,010)$ quando comparados ao grupo controle.

CONCLUSÃo: Prática esportiva prévia (durante infância e adolescência) foi associada com redução da gordura corporal e ser fisicamente ativo ao longo da vida foi associado à redução da gordura corporal e proteína c-reativa.

PALAVRAS-CHAVE: Atividade motora. Esportes. Doença crônica. Exercício. 


\section{REFERENCES}

1. Lee IM, Shiroma EJ, Lobelo F, Puska P, Blair SN, Katzmarzyk PT; Lancet Physical Activity Series Working Group. Effect of physical inactivity on major non-communicable diseases worldwide: an analysis of burden of disease and life expectancy. Lancet. 2012;380(9838):219-29.

2. Elhakeem A, Murray ET, Cooper R, Kuh D, Whincup P, Hardy R. Leisure-time physical activity across adulthood and biomarkers of cardiovascular disease at age 60-64: a prospective cohort study. Atherosclerosis. 2018;269:279-87.

3. Power C, Pinto Pereira SM, Law C, Ki M. Obesity and risk factors for cardiovascular disease and type 2 diabetes: investigating the role of physical activity and sedentary behaviour in mid-life in the 1958 British cohort. Atherosclerosis. 2014;233(2):363-9.

4. Hallal PC, Victora CG, Azevedo MR, Wells JC. Adolescent physical activity and health: a systematic review. Sports Med. 2006;36(12):1019-30.

5. Fernandes RA, Coelho-e-Silva MJ, Spiguel Lima MC, Cayres SU, Codogno IS, Lira FS. Possible underestimation by sports medicine of the effects of early physical exercise practice on the prevention of diseases in adulthood. Curr Diabetes Rev. 2015;11(3):201-5.

6. White AI, Sandler DP, Bolick SC, Xu Z, Taylor |A, DeRoo LA. Recreational and household physical activity at different time points and DNA global methylation. Eur J Cancer. 2013;49(9):2199-206.

7. Fernandes RA, Zanesco A. Early physical activity promotes lower prevalence of chronic diseases in adulthood. Hypertens Res. 2010;33(9):926-31.

8. Silva DR, Werneck AO, Collings PI, Fernandes RA, Barbosa DS, Ronque ERV, et al. Physical activity maintenance and metabolic risk in adolescents. J Public Health (Oxf). 2018;40(3):493-500.
9. Lima MCS, Cayres SU, Machado-Rodrigues A, Coelho-e-Silva MJ, Kemper HCG, Fernandes RA. Early sport practice promotes better metabolic profile independently of current physical activity. Med Sport [Internet]. 2014;18(4):172-8

10. Sociedade Brasileira de Cardiologia; Sociedade Brasileira de Hipertensão; Sociedade Brasileira de Nefrologia. VI Brazilian Guidelines on Hypertension. Arq Bras Cardiol. 2010;95(1 Suppl):1-51.

11. Meng C, Sun M, Wang Z, Fu Q, Cao M, Zhu Z, et al. Insulin sensitivity and beta-cell function are associated with arterial stiffness in individuals without hypertension. J Diabetes Res. 2013;2013:151675.

12. Sorić M, Jembrek Gostović M, Gostović M, Hočevar M, Mišigoj-Duraković M. Tracking of BMI, fatness and cardiorespiratory fitness from adolescence to middle adulthood: the Zagreb Growth and Development Longitudinal Study. Ann Hum Biol. 2014;41(3):238-43.

13. Rönn $T$, Volkov $P$, Davegårdh $C$, Dayeh $T$, Hall E, Olsson AH, et al. A six months exercise intervention influences the genome-wide DNA methylation pattern in human adipose tissue. PLoS Genet. 2013;9(6):e1003572.

14. Palmefors $H$, DuttaRoy $S$, Rundqvist $B$, Börjesson $M$. The effect of physical activity or exercise on key biomarkers in atherosclerosis: a systematic review. Atherosclerosis. 2014;235(1):150-61.

15. Murray ET, Hardy R, Hughes A, Wills A, Sattar N, Deanfield J, et al. Overweight across the life course and adipokines, inflammatory and endothelial markers at age 60-64 years: evidence from the 1946 birth cohort. Int J Obes (Lond). 2015;39(6):1010-8.

16. Lane JT, Mack-Shipman LR, Anderson JC, Moore TE, Erickson JM, Ford TC, et al. Comparison of CT and dual-energy DEXA using a modified trunk compartment in the measurement of abdominal fat. Endocrine. 2005;27(3):295-9. 